\title{
Effect of packaging on phenols, flavonoids and antioxidant characteristics of mechanical cabinet dried wild pomegranate (Punica granatum L.) arils
}

\author{
Abhimanyu Thakur* iD \\ Department of Food Science and Technology, Dr YS Parmar University of Horticulture and \\ Forestry, Nauni, Solan-173230 (Himachal Pradesh), India

\section{NS Thakur} \\ Department of Food Science and Technology, Dr YS Parmar University of Horticulture and \\ Forestry, Nauni, Solan-173230 (Himachal Pradesh), India \\ Hamid \\ Department of Food Science and Technology, Dr YS Parmar University of Horticulture and \\ Forestry, Nauni, Solan-173230 (Himachal Pradesh), India \\ Sunakshi Gautam \\ Department of Food Science and Technology, Dr YS Parmar University of Horticulture and \\ Forestry, Nauni, Solan-173230 (Himachal Pradesh), India \\ ${ }^{*}$ Corresponding author. E-mail: abhimanyuthakurprashar@gmail.com
}

\section{Article Info}

https://doi.org/10.31018/

jans.v13i1.2456

Received: December 11, 2020

Revised: February 10, 2021

Accepted: February 17, 2021

\section{How to Cite}

Thakur, A. et al. (2021). Effect of packaging on phenols, flavonoids and antioxidant characteristics of mechanical cabinet dried wild pomegranate (Punica granatum L.) arils. Journal of Applied and Natural Science, 13(1): 101 - 109. https://doi.org/10.31018/ jans.v13i1.2456

\begin{abstract}
Wild pomegranate (Punica granatum L.) fruit arils with high acid content are processed into dried arils (anardana) which is used as an ingredient in various medicinal formulations and culinary preparations. The various phenols and flavonoids are responsible for the antioxidant activity of anardana which signifies its functional benefits. The advanced packaging techniques like vacuum packaging, can retain higher antioxidant activity characteristics during storage. So, the present studies were carried out to compare the effect of packaging on total phenols, flavonoids, DPPH (2, 2-diphenyl-1-picrylhydrazyl) antioxidant activity, metal chelating activity, FRAP (ferric reducing antioxidant power) and reducing power of anardana prepared in mechanical cabinet drier. Anardana was packed in different packaging materials and stored under ambient and refrigerated temperature conditions. The overall effect of storage during 12 months revealed that there was a significant $(p<0.05)$ decrease in total phenols $(180.95$ to $161.76 \mathrm{mg} \mathrm{GAE} / 100 \mathrm{~g}$ ), flavonoids ( 40.60 to $32.66 \mathrm{mg} \mathrm{QuE} / 100 \mathrm{~g}$ ), DPPH antioxidant activity (61.23 to $56.13 \%$ ), metal chelating activity (22.25 to $19.37 \%)$, FRAP (34.60 to $\left.31.73 \mu \mathrm{M} \mathrm{Fe}{ }^{2+} / 100 \mathrm{~g}\right)$ and reducing power (0.610 to 0.521$)$ which was observed less in anardana packed in ALPV (aluminium laminated pouches with vacuum) followed by ALP (aluminium laminated pouches) and gunny bags. Due to slower rates of degradation of various antioxidant compounds, the changes after 12 months of storage were lower under refrigerated conditions. The total phenols, flavonoids and DPPH antioxidant activity were reduced from 180.95 to 167.24 and $156.28 \mathrm{mg} \mathrm{GAE} / 100 \mathrm{~g}, 40.60$ to 34.95 and $30.37 \mathrm{mg} \mathrm{QuE} / 100 \mathrm{~g}$ and 61.23 to 57.99 and $54.27 \%$ in refrigerated and ambient temperature conditions, respectively.
\end{abstract}

Keywords: Antioxidants, Dried arils, Flavonoids, Packaging, Phenols, Vacuum

\section{INTRODUCTION}

Wild pomegranate (Punica granatum L.) belonging to Punicaceae family is an important wild fruit crop which resembles the cultivated pomegranate for its various morphological characteristics. The wild genotypes have high titratable acid content with low sugar which results in a lower sugar: acid ratio and all wild pomegranates are classified with a sour taste (Sakar, 2016). It is native from Iran to the Himalayas in northern India and mainly distributed in central Asia from Iran, Turkmenistan to subtropical tracts of northern India at an altitude of 1000 to $1500 \mathrm{~m}$ above mean sea level (Holland et al., 2009; Jaiswal et al., 2010; Rawat et al., 2012).

Pomegranate fruit along with its wild forms is an important source of antioxidant compounds like phenols, 
flavonoids and hydrolyzable tannins (punicalagin, gallic and ellagic acid) and these compounds strengthen the immune function and lower down the risk of infection, cardiovascular diseases and cancer (Aloqbi et al., 2016; Sakar, 2016; Thakur et al., 2018; Thakur et al. 2019, Hamid et al., 2020a, Hamid et al., 2020b). Phenolic compounds have free radical scavenging abilities, anti-mutagenic and anti-carcinogenic activities and can reduce the risk of cardiovascular and carcinogenic diseases (Nakamura et al., 2003). Flavonoids are the most abundant plant polyphenols occurring in fruits with strong antioxidant activity and disease-preventing properties against cancer and cardiovascular diseases (Wang and Ho, 2009; Cecere et al., 2016). The various flavonoids like anthocyanins, ellagic acid derivatives and hydrolysable tannins (punicalagin, gallic and ellagic acid) are responsible for the antioxidant activity of pomegranate fruit and a very high antioxidant activity in the wild and cultivated pomegranate fruit extracts (peel, juice and seeds) have been observed by various researchers (Gill et al., 2000; Aviram et al., 2000; Singh et al., 2002; Thakur et al., 2018; Hamid et al., 2020a).

Wild pomegranate fruit is highly acidic in nature which is not fit for fresh consumption and its arils are dried to yield a value-added processed product known as anardana (Thakur et al., 2020a). The dried arils are used as an acidulant in culinary purposes in place of tamarind and dried green mango and every year it is collected from the production areas which are sold in the popular markets of the country and abroad (Bakshi et al., 2013; Dhumal et al., 2014; Thakur et al., 2017). The dried arils, rich in antioxidants compounds are used in the preparation of digestive candies and in formulations of various Ayurvedic and Unnani medicines which are helpful in curing a number of ailments (Dhumal et al., 2014; Hota et al., 2017, Hamid et al., 2020c; Thakur et al., 2020b). No work has been carried out on effect of packaging and storage on antioxidant properties of dried wild pomegranate arils. Packaging plays an important role in retaining the nutritional, sensory and microbiological quality along with enhanced shelf life of any processed product during handling, transportation and storage (Sharma and Thakur, 2019). The advanced packaging techniques like vacuum packaging over traditional packaging (gunny bags) can retain higher phenols, flavonoids and antioxidant activity characteristics during storage. So the present studies were carried out to compare the effect of storage and packaging materials on total phenols, flavonoids and antioxidant activity of dried wild pomegranate arils prepared in mechanical cabinet drier.

\section{MATERIALS AND METHODS}

Procurement of raw material and preparation of dried arils: The wild pomegranate (Punica granatum
L.) fruits (Fig. 1) were procured from Karsog area of Mandi district of Himachal Pradesh, India (1265 m above mean sea level). The extracted arils were used for the preparation of dried arils as per the method suggested by Thakur et al. (2010). The pre-treated arils were spread on the perforated steel trays and dried at a constant temperature at $60 \pm 2{ }^{\circ} \mathrm{C}$ inside a mechanical cabinet drier.

\section{Packaging and storage}

The dried arils were packed in different packaging materials (Fig. 2) like gunny bags, aluminium laminated pouches (ALP) and aluminium laminated pouches with a vacuum (ALPV). All the packages were stored under ambient temperature $\left(9.8-24{ }^{\circ} \mathrm{C}\right)$ and refrigerated temperature $\left(4-7{ }^{\circ} \mathrm{C}\right)$ for a period of 12 months and the overall effect of the storage period, storage conditions and packaging was analyzed for changes in total phenols, flavonoids and antioxidant activity.

\section{Total phenols}

Total phenols content of dried arils was determined by Folin-Ciocalteu procedure given by Singleton and Rossi (1965) in which absorbance was measured at $765 \mathrm{~nm}$ in a spectrophotometer against a water blank. The concentration was determined as per the standard procedure from the standard curve. A standard calibration curve of gallic acid using its different concentrations was prepared. Absorbance was then plotted against concentration and concentration of total phenols in the sample was calculated and expressed as $\mathrm{mg} / 100 \mathrm{~g}$ of sample.

\section{Total flavonoids}

Total flavonoids content of the samples was estimated according to the method of llahy et al. (2011). $0.1 \mathrm{ml}$ of methanolic extract $(1 \mathrm{ml} / \mathrm{g}$ sample in $10 \mathrm{ml}$ methanol for $12 \mathrm{~h}$ ) was mixed with $1 \mathrm{ml}$ of $80 \%$ ethanol. $0.5 \mathrm{ml}$ of aliquote was added to a test tube containing $0.1 \mathrm{ml}$ of 10 per cent aluminium nitrate, $0.1 \mathrm{ml}$ of $1 \mathrm{M}$ potassium acetate and $4.3 \mathrm{ml}$ of 80 per cent ethanol. The mixture was kept as such for 40 minutes at room temperature and absorbance at $415 \mathrm{~nm}$ was measured. Flavonoid content was calculated from standard curve using quercetin as standard and expressed as $\mathrm{mg}$ QuE/100 g.

\section{Antioxidant activity}

DPPH (2, 2-Diphenyl-1-picrylhydrazyl) radical scavenging activity (\%) was measured according to the method of Brand-Williams et al. (1995). Determination of \% metal chelating activity was carried out by the method of Dinis et al. (1994). Ferric reducing antioxidant power (FRAP) of the dried arils in terms of $\mu \mathrm{M} \mathrm{Fe}^{2+} / 100 \mathrm{~g}$ was estimated as per the method of Benzie and Strain (1996). Reducing power in terms of absorbance of the 


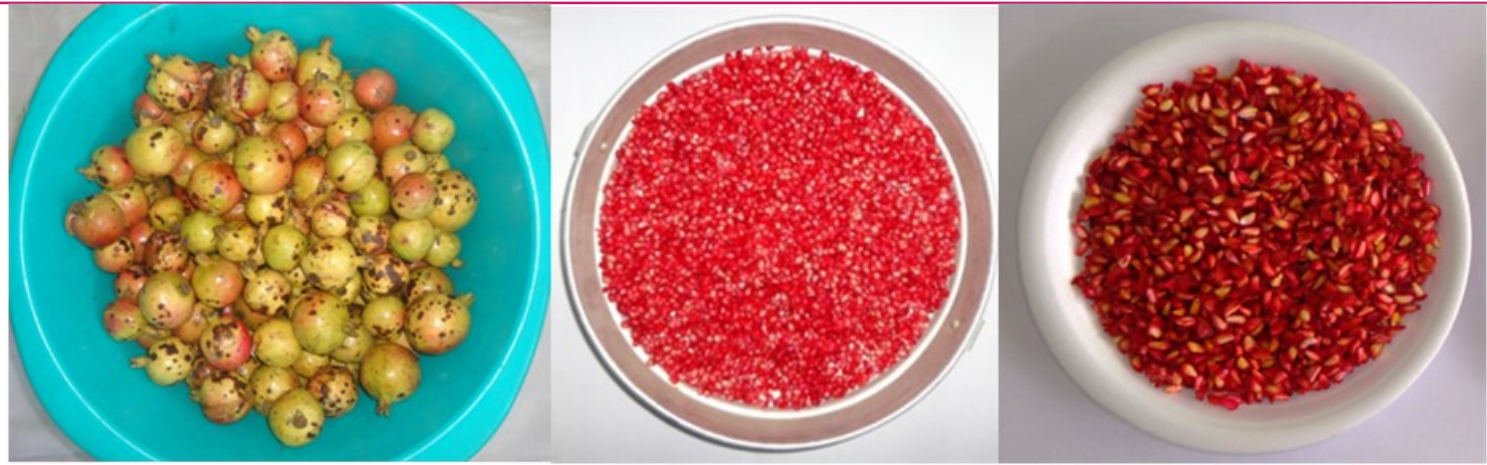

Fig. 1. Wild pomegranate fruits, extracted arils and mechanical cabinet dried arils.

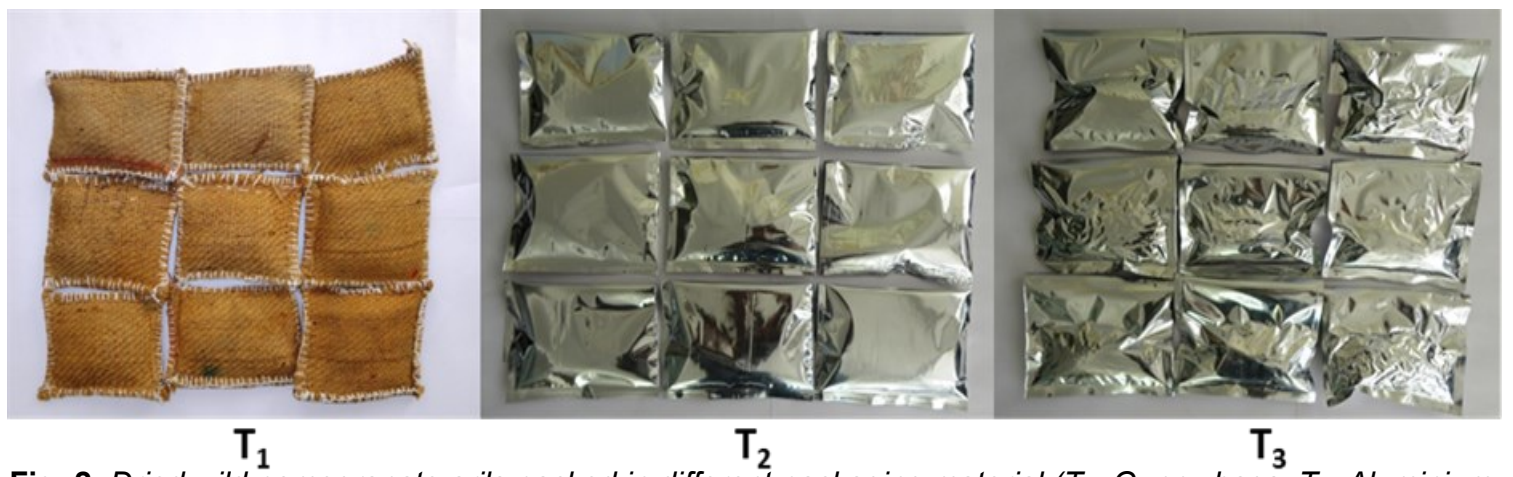

Fig. 2. Dried wild pomegranate arils packed in different packaging material ( $T_{1}$ : Gunny bags, $T_{2}$ : Aluminium laminated pouches and $T_{3}$ : Aluminium laminated pouches with vacuum.

sample extract at $700 \mathrm{~nm}$ was determined as per the method of Oktay et al. (2003).

\section{Statistical analysis}

The data on various quality characteristics were replicated three times and analyzed by CRD (factorial). The significance $(p<0.05)$ or otherwise of data obtained from various experiments was judged with the help of $F$ -Table using OPSTAT software.

\section{RESULTS AND DISCUSSION}

\section{Total phenols}

Data pertaining to total phenols content given in Table 1 indicate that there was a general decreasing trend in the total phenols content of dried arils during entire storage period. The overall effect of storage conditions $(\mathrm{V})$, storage period (S) and packaging materials ( $\mathrm{T}$ ) on the total phenols content of dried arils revealed that after 12 months it decreased from 180.95 to $161.76 \mathrm{mg}$ GAE/100 g, higher (174.14 mg GAE/100 g) was found in refrigerated storage conditions and lower $(168.71 \mathrm{mg}$ $\mathrm{GAE} / 100 \mathrm{~g}$ ) in ambient storage conditions. The higher (175.20 mg GAE/100 g) total phenols content was recorded in dried arils packed in ALP with vacuum as compared to gunny bags (166.78 mg GAE/100 g) while comparing the overall effect of packaging materials on total phenols content of dried arils.

Total phenols content of dried arils decreased signifi- cantly during storage which might be due to oxidation and hydrolytic degradation of bioactive compounds, including phenols (Kotsiou and Tasioula-Margari, 2016). In the present study, dried arils stored under refrigerated conditions retained higher total phenols content which might be due to the slower rate of oxidation reactions under low-temperature conditions. Product packed in ALP with vacuum retained maximum total phenols which might be due to the better conditions inside the pouch which restricted the moisture and oxygen movement inside the pouch and minimised the oxidative and hydrolytic changes of phenolic compounds as compared to gunny bags. The decrease in total phenols content of dried arils of wild pomegranate fruit during storage has also been observed by Bhat et al. (2014) and Sharma and Thakur (2016). Further, they have observed the minimum losses of total phenols in dried arils in ALP under refrigerated storage conditions as compared to PEP and thermoform trays.

\section{Total flavonoids}

An appraisal of data given in Table 2 revealed that during entire storage, there was a general decreasing trend in total flavonoids content of dried arils prepared in mechanical cabinet drier. The total flavonoids content of dried arils exhibited a significant $(p<0.05)$ decrease from 40.60 to $32.66 \mathrm{mg} \mathrm{QuE} / 100 \mathrm{~g}$ during storage. Further, while comparing the overall effect of storage conditions $(\mathrm{V})$ it was found that maximum (37.89 mg QuE $/ 100 \mathrm{~g}$ ) total flavonoids content was retained 
Thakur, A. et al. / J. Appl. \& Nat. Sci. 13(1): 101 - 109 (2021)

Table 1. Effect of storage on total phenols (mg GAE/100 g) of dried wild pomegranate arils prepared under mechanical cabinet drier.

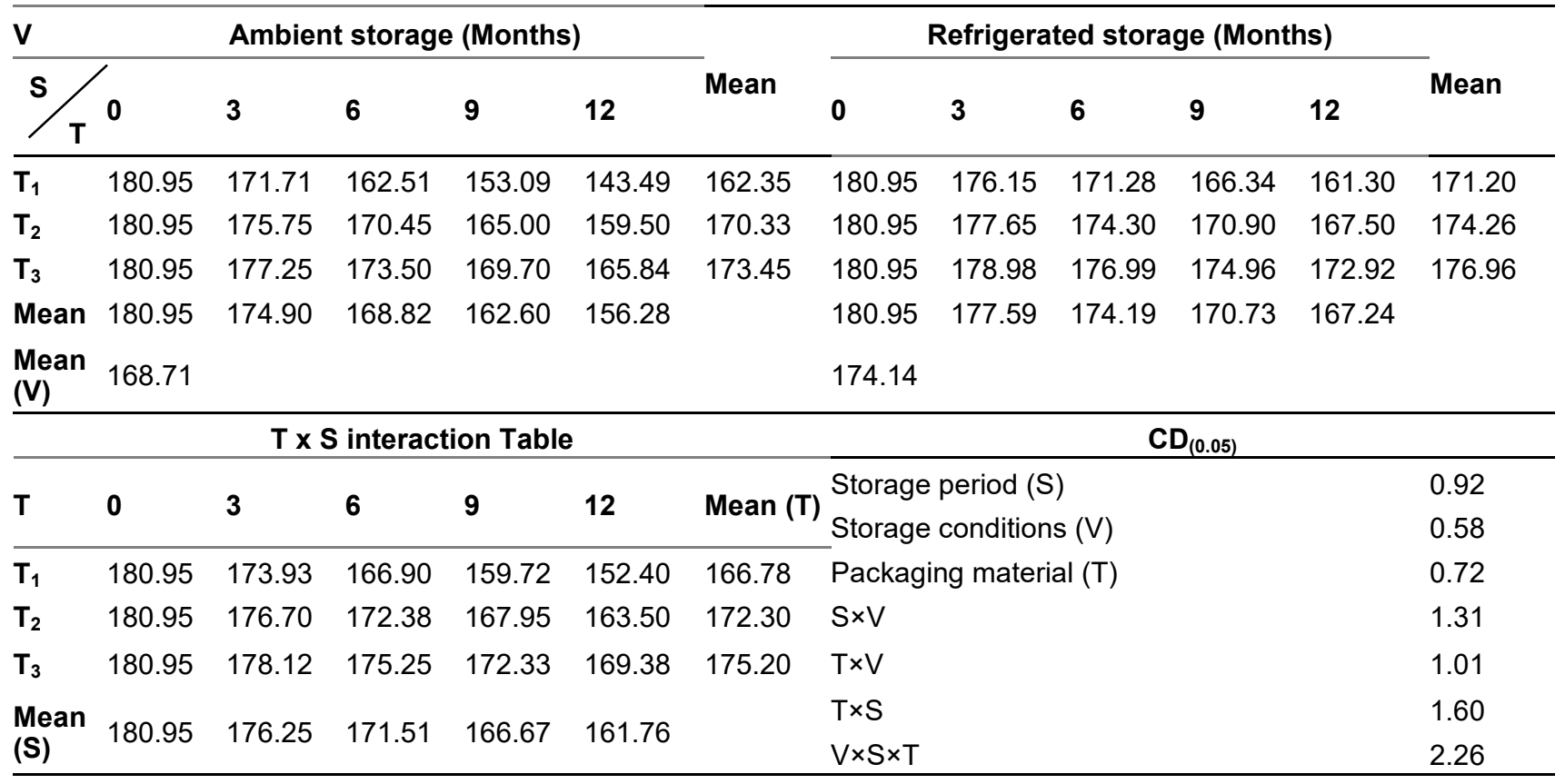

$\mathbf{T}_{1}$ : Gunny bag, $\mathbf{T}_{2}$ : Aluminium laminated pouch, $\mathbf{T}_{3}$ : Aluminium laminated pouch with vacuum

Table 2. Effect of storage on total flavonoids ( $\mathrm{mg} Q \mathrm{QuE} / 100 \mathrm{~g}$ ) of dried wild pomegranate arils prepared under mechanical cabinet drier.

\begin{tabular}{|c|c|c|c|c|c|c|c|c|c|c|c|c|}
\hline \multirow{2}{*}{$\begin{array}{l}\mathrm{v} \\
\mathrm{s}\end{array}$} & \multicolumn{5}{|c|}{ Ambient storage (Months) } & \multirow[b]{2}{*}{ Mean } & \multicolumn{5}{|c|}{ Refrigerated storage (Months) } & \multirow[b]{2}{*}{ Mean } \\
\hline & 0 & 3 & 6 & 9 & 12 & & 0 & 3 & 6 & 9 & 12 & \\
\hline $\mathrm{T}_{1}$ & 40.60 & 37.15 & 32.14 & 27.34 & 22.15 & 31.88 & 40.60 & 38.76 & 36.87 & 34.04 & 32.19 & 36.49 \\
\hline $\mathrm{T}_{2}$ & 40.60 & 38.82 & 36.83 & 34.75 & 31.23 & 36.45 & 40.60 & 39.28 & 38.89 & 36.41 & 34.89 & 38.01 \\
\hline $\mathbf{T}_{3}$ & 40.60 & 39.58 & 39.14 & 38.12 & 37.74 & 39.03 & 40.60 & 39.60 & 39.10 & 38.71 & 37.77 & 39.16 \\
\hline Mean & 40.60 & 38.52 & 36.04 & 33.40 & 30.37 & & 40.60 & 39.21 & 38.29 & 36.39 & 34.95 & \\
\hline $\begin{array}{l}\text { Mean } \\
\text { (V) }\end{array}$ & 35.79 & & & & & & 37.89 & & & & & \\
\hline \multicolumn{7}{|c|}{ T X S interaction Table } & \multicolumn{6}{|c|}{$\mathrm{CD}_{(0.05)}$} \\
\hline \multirow{2}{*}{$T$} & \multirow{2}{*}{0} & \multirow{2}{*}{3} & \multirow{2}{*}{6} & \multirow{2}{*}{9} & \multirow{2}{*}{12} & \multirow{2}{*}{$\begin{array}{l}\text { Mean } \\
\text { (T) }\end{array}$} & \multirow{2}{*}{\multicolumn{3}{|c|}{$\begin{array}{l}\text { Storage period }(\mathrm{S}) \\
\text { Storage conditions }(\mathrm{V})\end{array}$}} & & & 0.31 \\
\hline & & & & & & & & & & & & 0.20 \\
\hline $\mathrm{T}_{1}$ & 40.60 & 37.95 & 34.51 & 30.69 & 27.17 & 34.18 & \multicolumn{3}{|c|}{ Packaging material $(\mathrm{T})$} & & & 0.24 \\
\hline $\mathrm{T}_{2}$ & 40.60 & 39.05 & 37.86 & 35.58 & 33.06 & 37.23 & \multicolumn{3}{|l|}{$S \times V$} & & & 0.45 \\
\hline$T_{3}$ & 40.60 & 39.59 & 39.12 & 38.42 & 37.75 & 39.10 & \multicolumn{3}{|l|}{$T \times V$} & & & 0.34 \\
\hline \multirow{2}{*}{$\begin{array}{l}\text { Mean } \\
\text { (S) }\end{array}$} & \multirow{2}{*}{40.60} & \multirow{2}{*}{38.87} & \multirow{2}{*}{37.16} & \multirow{2}{*}{34.89} & \multirow{2}{*}{32.66} & & \multirow{2}{*}{\multicolumn{3}{|c|}{$\begin{array}{l}T \times S \\
V \times S \times T\end{array}$}} & & & 0.55 \\
\hline & & & & & & & & & & & & 0.77 \\
\hline
\end{tabular}

$\mathrm{T}_{1}$ : Gunny bag, $\mathrm{T}_{2}$ : Aluminium laminated pouch, $\mathrm{T}_{3}$ : Aluminium laminated pouch with vacuum

under refrigerated storage conditions as compared to ambient storage conditions (35.79 mg QuE/100 g). The overall effect of packaging materials $(T)$ indicates that higher $(39.10 \mathrm{mg} \mathrm{QuE} / 100 \mathrm{~g}$ ) total flavonoids content was retained in ALP with vacuum as compared to gunny bag (34.18 mg QuE /100 g) during 12 months of storage period.

The total flavonoids content of dried arils decreased significantly during storage which might be attributed to their oxidation process and their involvement in nonenzymatic reactions. Dried arils stored under refrigerated conditions retained more total flavonoid content due 
Thakur, A. et al. / J. Appl. \& Nat. Sci. 13(1): 101 - 109 (2021)

Table 3. Effect of storage on DPPH antioxidant activity (\%) of dried wild pomegranate arils prepared under mechanical cabinet drier.

\begin{tabular}{|c|c|c|c|c|c|c|c|c|c|c|c|c|}
\hline \multirow{2}{*}{$\begin{array}{l}\mathrm{V} \\
\mathrm{s}\end{array}$} & \multicolumn{5}{|c|}{ Ambient storage (Months) } & \multirow[b]{2}{*}{ Mean } & \multicolumn{5}{|c|}{ Refrigerated storage (Months) } & \multirow{2}{*}{ Mean } \\
\hline & 0 & 3 & 6 & 9 & 12 & & 0 & 3 & 6 & 9 & 12 & \\
\hline $\mathrm{T}_{1}$ & 61.23 & 56.15 & 54.42 & 51.02 & 47.95 & 54.15 & 61.23 & 59.45 & 59.01 & 58.12 & 56.41 & 58.84 \\
\hline $\mathrm{T}_{2}$ & 61.23 & 59.75 & 58.94 & 57.85 & 56.40 & 58.83 & 61.23 & 60.40 & 59.89 & 59.12 & 58.41 & 59.81 \\
\hline$T_{3}$ & 61.23 & 60.40 & 59.92 & 59.00 & 58.45 & 59.80 & 61.23 & 60.75 & 60.23 & 59.75 & 59.15 & 60.22 \\
\hline Mean & 61.23 & 58.77 & 57.76 & 55.96 & 54.27 & & 61.23 & 60.20 & 59.71 & 59.00 & 57.99 & \\
\hline $\begin{array}{l}\text { Mean } \\
\text { (V) }\end{array}$ & 57.60 & & & & & & 59.63 & & & & & \\
\hline \multicolumn{7}{|c|}{$\mathrm{T} \times \mathrm{S}$ interaction Table } & \multicolumn{6}{|c|}{$\mathrm{CD}_{(0.05)}$} \\
\hline $\mathbf{T}$ & 0 & 3 & 6 & 9 & 12 & $\begin{array}{l}\text { Mean } \\
\text { (T) }\end{array}$ & $\begin{array}{l}\text { Storag } \\
\text { Storag }\end{array}$ & $\begin{array}{l}\text { period } \\
\text { conditic }\end{array}$ & $\begin{array}{l}\text { s }(V) \\
\text { ins }\end{array}$ & & & $\begin{array}{l}0.21 \\
0.13\end{array}$ \\
\hline $\mathrm{T}_{1}$ & 61.23 & 57.80 & 56.72 & 54.57 & 52.18 & 56.50 & Packa & ng mate & al $(T)$ & & & 0.17 \\
\hline $\mathrm{T}_{2}$ & 61.23 & 60.08 & 59.42 & 58.49 & 57.41 & 59.32 & $S \times V$ & & & & & 0.30 \\
\hline $\mathbf{T}_{3}$ & 61.23 & 60.58 & 60.08 & 59.38 & 58.80 & 60.01 & $T \times V$ & & & & & 0.23 \\
\hline $\begin{array}{l}\text { Mean } \\
\text { (S) }\end{array}$ & 61.23 & 59.48 & 58.74 & 57.48 & 56.13 & & $\begin{array}{l}T \times S \\
V \times S \times 7\end{array}$ & & & & & $\begin{array}{l}0.37 \\
0.52\end{array}$ \\
\hline
\end{tabular}

$\mathbf{T}_{1}$ : Gunny bag, $\mathbf{T}_{2}$ : Aluminium laminated pouch, $\mathbf{T}_{3}$ : Aluminium laminated pouch with vacuum

Table 4. Effect of storage on metal chelating activity (\%) of dried wild pomegranate arils prepared under mechanical cabinet drier.

\begin{tabular}{|c|c|c|c|c|c|c|c|c|c|c|c|c|}
\hline \multirow{2}{*}{$\begin{array}{l}\mathrm{V} \\
\mathrm{s}\end{array}$} & \multicolumn{5}{|c|}{ Ambient storage (Months) } & \multirow[b]{2}{*}{ Mean } & \multicolumn{5}{|c|}{ Refrigerated storage (Months) } & \multirow[b]{2}{*}{ Mean } \\
\hline & 0 & 3 & 6 & 9 & 12 & & 0 & 3 & 6 & 9 & 12 & \\
\hline $\mathbf{T}_{1}$ & 22.25 & 19.00 & 17.45 & 16.08 & 15.12 & 17.98 & 22.25 & 20.70 & 20.01 & 19.75 & 19.11 & 20.36 \\
\hline$T_{2}$ & 22.25 & 21.05 & 20.31 & 19.35 & 18.47 & 20.29 & 22.25 & 21.74 & 21.50 & 21.15 & 20.82 & 21.49 \\
\hline$T_{3}$ & 22.25 & 22.11 & 21.90 & 21.52 & 21.24 & 21.80 & 22.25 & 22.22 & 22.10 & 21.80 & 21.45 & 21.96 \\
\hline Mean & 22.25 & 20.72 & 19.89 & 18.98 & 18.28 & & 22.25 & 21.55 & 21.20 & 20.90 & 20.46 & \\
\hline $\begin{array}{l}\text { Mean } \\
\text { (V) }\end{array}$ & 20.02 & & & & & & 21.27 & & & & & \\
\hline \multicolumn{7}{|c|}{ T X S interaction Table } & \multicolumn{6}{|c|}{$C D_{(0.05)}$} \\
\hline $\mathbf{T}$ & 0 & 3 & 6 & \multirow[t]{2}{*}{9} & 12 & \multirow{2}{*}{$\begin{array}{l}\text { Mean } \\
\text { (T) }\end{array}$} & \multirow{2}{*}{\multicolumn{3}{|c|}{$\begin{array}{l}\text { Storage period (S) } \\
\text { Storage conditions (V) }\end{array}$}} & & & 0.21 \\
\hline & & & & & & & & & & & & \\
\hline $\mathrm{T}_{1}$ & 22.25 & 19.85 & 18.73 & 17.92 & 17.12 & 19.17 & Packas & ng mat & al (T) & & & 0.16 \\
\hline $\mathrm{T}_{2}$ & 22.25 & 21.40 & 20.91 & 20.25 & 19.65 & 20.89 & $S \times V$ & & & & & 0.30 \\
\hline$T_{3}$ & 22.25 & 22.17 & 22.00 & 21.66 & 21.35 & 21.88 & $T \times V$ & & & & & 0.23 \\
\hline $\begin{array}{l}\text { Mean } \\
\text { (S) }\end{array}$ & 22.25 & 21.14 & 20.55 & 19.94 & 19.37 & & $\begin{array}{l}T \times S \\
V \times S \times T\end{array}$ & & & & & $\begin{array}{l}0.37 \\
0.52\end{array}$ \\
\hline
\end{tabular}

$\mathbf{T}_{1}$ : Gunny bag, $\mathbf{T}_{2}$ : Aluminium laminated pouch, $\mathbf{T}_{3}$ : Aluminium laminated pouch with vacuum

to the slower rate of oxidation reactions under lowtemperature conditions as the stability of flavonoids is highly temperature-dependent. Product packed in ALP with vacuum retained maximum total flavonoids which might be due to the better conditions inside the pouch which restricted the moisture and oxygen movement inside the pouch and minimised the oxidative changes of flavonoids as compared to gunny bags. The maximum rate of flavonoid degradation observed in gunny bags might be due to its poor barrier property towards light which led to the photo-oxidation of flavonoids. The above results for decrease in total flavo- 
Thakur, A. et al. / J. Appl. \& Nat. Sci. 13(1): 101 - 109 (2021)

Table 5. Effect of storage on FRAP $\left(\mu \mathrm{M} \mathrm{Fe}^{2+} / 100 \mathrm{~g}\right)$ of dried wild pomegranate arils prepared under mechanical cabinet drier.

\begin{tabular}{|c|c|c|c|c|c|c|c|c|c|c|c|c|}
\hline \multirow{2}{*}{$\frac{\mathrm{V}}{\mathrm{s} / \mathrm{T}}$} & \multicolumn{5}{|c|}{ Ambient storage (Months) } & \multirow[b]{2}{*}{ Mean } & \multicolumn{5}{|c|}{ Refrigerated storage (Months) } & \multirow[b]{2}{*}{ Mean } \\
\hline & 0 & 3 & 6 & 9 & 12 & & 0 & 3 & 6 & 9 & 12 & \\
\hline$T_{1}$ & 34.60 & 31.10 & 29.30 & 27.52 & 25.60 & 29.62 & 34.60 & 34.20 & 33.76 & 33.28 & 32.75 & 33.72 \\
\hline$T_{2}$ & 34.60 & 33.75 & 32.80 & 32.29 & 31.35 & 32.96 & 34.60 & 34.40 & 34.17 & 33.92 & 33.66 & 34.15 \\
\hline$T_{3}$ & 34.60 & 34.20 & 33.96 & 33.42 & 32.98 & 33.83 & 34.60 & 34.47 & 34.33 & 34.19 & 34.04 & 34.33 \\
\hline Mean & 34.60 & 33.02 & 32.02 & 31.08 & 29.98 & & 34.60 & 34.36 & 34.09 & 33.80 & 33.48 & \\
\hline $\begin{array}{l}\text { Mean } \\
\text { (V) }\end{array}$ & 32.14 & & & & & & 34.06 & & & & & \\
\hline \multicolumn{7}{|c|}{ T x S interaction Table } & \multicolumn{6}{|c|}{$C D_{(0.05)}$} \\
\hline$T$ & 0 & 3 & 6 & 9 & 12 & $\begin{array}{l}\text { Mean } \\
\text { (T) }\end{array}$ & $\begin{array}{l}\text { Storag } \\
\text { Storag }\end{array}$ & $\begin{array}{l}\text { period } \\
\text { conditic }\end{array}$ & $\begin{array}{l}\text { s) } \\
\text { s }(V)\end{array}$ & & & $\begin{array}{l}0.21 \\
0.13\end{array}$ \\
\hline$\overline{T_{1}}$ & 34.60 & 32.65 & 31.53 & 30.40 & 29.18 & 31.67 & Packa & ng mate & ial $(T)$ & & & 0.16 \\
\hline$T_{2}$ & 34.60 & 34.08 & 33.49 & 33.11 & 32.51 & 33.55 & $S \times V$ & & & & & 0.30 \\
\hline $\mathrm{T}_{3}$ & 34.60 & 34.34 & 34.15 & 33.81 & 33.51 & 34.08 & $T \times V$ & & & & & 0.23 \\
\hline $\begin{array}{l}\text { Mean } \\
\text { (S) }\end{array}$ & 34.60 & 33.69 & 33.05 & 32.44 & 31.73 & & $\begin{array}{l}T \times S \\
V \times S \times 7\end{array}$ & & & & & $\begin{array}{l}0.36 \\
0.51\end{array}$ \\
\hline
\end{tabular}

$T_{1}$ : Gunny bag, $T_{2}$ : Aluminium laminated pouch, $T_{3}$ : Aluminium laminated pouch with vacuum

Table 6. Effect of storage on reducing power (absorbance at $700 \mathrm{~nm}$ ) of dried wild pomegranate arils prepared under mechanical cabinet drier.

\begin{tabular}{|c|c|c|c|c|c|c|c|c|c|c|c|c|}
\hline \multirow{2}{*}{$\begin{array}{l}\mathrm{V} \\
\mathrm{s} / \mathrm{T}\end{array}$} & \multicolumn{5}{|c|}{ Ambient storage (Months) } & \multirow[b]{2}{*}{ Mean } & \multicolumn{5}{|c|}{ Refrigerated storage (Months) } & \multirow[b]{2}{*}{ Mean } \\
\hline & 0 & 3 & 6 & 9 & 12 & & 0 & 3 & 6 & 9 & 12 & \\
\hline$\overline{T_{1}}$ & 0.610 & 0.482 & 0.450 & 0.414 & 0.373 & 0.466 & 0.610 & 0.550 & 0.545 & 0.541 & 0.505 & 0.550 \\
\hline $\mathrm{T}_{2}$ & 0.610 & 0.568 & 0.552 & 0.523 & 0.502 & 0.551 & 0.610 & 0.595 & 0.588 & 0.578 & 0.569 & 0.588 \\
\hline $\mathrm{T}_{3}$ & 0.610 & 0.603 & 0.594 & 0.585 & 0.580 & 0.594 & 0.610 & 0.608 & 0.605 & 0.601 & 0.596 & 0.604 \\
\hline Mean & 0.610 & 0.551 & 0.532 & 0.507 & 0.485 & & 0.610 & 0.584 & 0.579 & 0.573 & 0.557 & \\
\hline $\begin{array}{l}\text { Mean } \\
\text { (V) }\end{array}$ & 0.537 & & & & & & 0.581 & & & & & \\
\hline \multicolumn{7}{|c|}{ T X S interaction Table } & \multicolumn{6}{|c|}{$C D_{(0.05)}$} \\
\hline $\mathbf{T}$ & 0 & 3 & 6 & 9 & 12 & $\begin{array}{l}\text { Mean } \\
\text { (T) }\end{array}$ & \multicolumn{5}{|c|}{$\begin{array}{l}\text { Storage period }(\mathrm{S}) \\
\text { Storage conditions }(\mathrm{V})\end{array}$} & $\begin{array}{l}0.03 \\
0.01\end{array}$ \\
\hline $\mathrm{T}_{1}$ & 0.610 & 0.516 & 0.498 & 0.478 & 0.439 & 0.508 & \multicolumn{5}{|c|}{ Packaging material $(\mathrm{T})$} & 0.02 \\
\hline $\mathrm{T}_{2}$ & 0.610 & 0.582 & 0.570 & 0.551 & 0.536 & 0.570 & \multicolumn{5}{|l|}{$S \times V$} & NS \\
\hline $\mathrm{T}_{3}$ & 0.610 & 0.606 & 0.600 & 0.593 & 0.588 & 0.599 & \multicolumn{5}{|l|}{$T \times V$} & 0.03 \\
\hline $\begin{array}{l}\text { Mean } \\
\text { (S) }\end{array}$ & 0.610 & 0.568 & 0.556 & 0.540 & 0.521 & & \multicolumn{5}{|c|}{$\begin{array}{l}T \times S \\
V \times S \times T\end{array}$} & $\begin{array}{l}0.05 \\
\text { NS }\end{array}$ \\
\hline
\end{tabular}

$\mathbf{T}_{1}$ : Gunny bag, $\mathbf{T}_{2}$ : Aluminium laminated pouch, $\mathbf{T}_{3}$ : Aluminium laminated pouch with vacuum

noids during storage are in conformity with the findings of Sonawane and Arya (2015) in dried Jambhul pulp.

\section{Antioxidant characteristics}

Data in Table 3 elucidated that the DPPH antioxidant activity of dried arils prepared in mechanical cabinet drier decreased significantly during the entire storage period. The antioxidant activity of dried arils prepared in mechanical cabinet drier decreased from 61.23 to 56.13 per cent. The lower $(57.60 \%)$ and higher $(59.63 \%)$ antioxidant activities were found in dried arils stored under ambient and refrigerated storage conditions, respectively. The overall effect of packaging material $(\mathrm{T})$ revealed that maximum $(60.01 \%)$ antioxidant activity of dried arils was found in ALP with vacuum as compared gunny bags (56.50\%). An appraisal of data (Table 4) revealed that there was a general decreasing 
trend in the metal chelating activity of dried arils during storage. The overall effect of storage period (S) revealed that metal chelating activity decreased from 22.25 to 19.37 per cent during storage. Further, while comparing the overall effect of storage conditions $(\mathrm{V})$ it was found that maximum $(21.27 \%)$ metal chelating activity was retained under refrigerated storage conditions as compared to ambient $(20.02 \%)$. The overall effect of packaging material $(\mathrm{T})$ indicated that maximum $(21.88 \%)$ metal chelating activity was found in ALP with vacuum as compared to gunny bags (19.17\%) after 12 months of storage period.

Table 5 revealed that during storage, there was a general decrease in FRAP of dried arils prepared in mechanical cabinet drier. The overall effect of storage period (S), storage conditions (V), and packaging material (T) on FRAP of dried arils showed that it decreased from 34.60 to $31.73 \mu \mathrm{M} \mathrm{Fe} e^{2+} / 100 \mathrm{~g}$ and retained higher (34.06 $\left.\mu \mathrm{M} \mathrm{Fe}{ }^{2+} / 100 \mathrm{~g}\right)$ in refrigerated conditions and lower $\left(32.14 \mu \mathrm{M} \mathrm{Fe} \mathrm{F}^{2+} / 100 \mathrm{~g}\right)$ in ambient storage conditions. The higher $\left(34.08 \mu \mathrm{M} \mathrm{Fe} \mathrm{Fe}^{2+} / 100 \mathrm{~g}\right) \mathrm{FRAP}$ was retained in ALP with vacuum as compared to gunny bags $\left(31.67 \mu \mathrm{M} \mathrm{Fe} e^{2+} / 100 \mathrm{~g}\right)$. An appraisal of data given in Table 6 revealed that there was a general decreasing trend in reducing the power of dried arils during the entire storage period of 12 months. The overall effect of storage period (S) reveals that reducing power in terms of absorbance decreased from 0.610 to 0.521 during storage. Further, while comparing the overall effect of storage conditions $(\mathrm{V})$ it was found that higher $(0.581)$ reducing power was found under refrigerated storage conditions as compared to ambient (0.537) storage conditions. The overall effect of packaging materials $(T)$ indicates that maximum (0.599) reducing power was retained in ALP with vacuum as compared to gunny bags (0.508).

During storage period of 12 months DPPH antioxidant activity, metal chelating activity, FRAP and reducing the power of dried arils decreased significantly $(p<0.05)$ which might be due to the degradation of its chemical characteristics like ascorbic acid, total phenols, flavonoids and anthocyanins and other reason could be the non-enzymatic browning reactions. The loss for above characteristics was lower in the dried arils stored under refrigerated temperature condition as compared to ambient which might be due to the slower rates of degradation of various antioxidant compounds present in the product which helped in the retention of higher antioxidant activity. The product packed in ALP with vacuum has retained higher antioxidant characteristics which might be due to the better conditions inside the pouch because of restricted moisture and oxygen movement inside the pouch and minimized the oxidative changes of antioxidant compounds as compared to gunny bags. In the case of gunny bags, the diffusion of gases and moisture is supposed to be a deleterious factor, which causes the most significant decrease in the antioxidant characteristics (Ergun et al., 2010). With the diffusion of oxygen inside the package, the concentration starts building up with storage and consequently, it starts the degradation of polyphenolic compounds and secondary metabolites (Mir et al., 2015). The decrease in antioxidant activity during storage of dried carrot roundels packed in ALP stored under ambient and refrigerated temperature conditions has also been observed by Kumar et al. (2020). A slight decrease in the metal chelating activity of candy prepared from quince fruit packed in polyethylene pouch, laminate and the plastic jar has also been observed by Mir et al. (2015). Muzzaffar et al. (2016) have also observed a decrease in FRAP and reducing the power of candy prepared from pumpkin stored under ambient temperature conditions.

\section{Conclusion}

The present study concluded that during 12 months of the storage period, the maximum total phenols, flavonoids and antioxidant characteristics of dried wild pomegranate (Punica granatum L.) arils were retained in aluminium laminated pouches with a vacuum which were stored under refrigerated storage conditions as compared to ALP and gunny bags. The maximum losses in the above quality characteristics of dried arils were observed in gunny bags at ambient temperature. The advanced packaging techniques like vacuum packaging retained higher total phenols, flavonoids and antioxidant activity characteristics during storage with respect to aluminium laminated pouch or traditional packaging i.e. gunny bags.

\section{Conflict of interest}

The authors declare that they have no conflict of interest.

\section{REFERENCES}

1. Aloqbi, A., Omar, U., Yousr, M., Grace, M., Lila M.A. et al. (2016). Antioxidant activity of pomegranate juice and punicalagin. Natural Science, 8(6), 235-246. https:// www.doi.org/10.4236/ns.2016.86028

2. Aviram, M., Dornfeld, L., Rosenblat, M., Volkova, N., Kaplan, M. et al. (2000). Pomegranate juice consumption reduces oxidative stress, atherogenic modifications to LDL, and platelet aggregation: studies in humans and in atherosclerotic apolipoprotein E-deficient mice. $\mathrm{Am} \mathrm{J}$ Clin Nutr., 71(5), 1062-1076. https://www.doi.org/10.1093/ ajcn/71.5.1062

3. Bakshi, P., Bhushan, B., Wali, V.K., Bakshi, M., Sharma, A. et al. (2013). Standardization of drying method and organoleptic evaluation of wild pomegranate (anardana) seeds. World Journal of Agricultural Sciences, 9(5), 397400. https://www.doi.org/10.5829/idosi.wjas.2013.9.5.17 
50

4. Benzie, I.F. \& Strain, J.J. (1996). The ferric reducing ability of plasma (FRAP) as a measure of antioxidant power: the FRAP assay. Anal Biochem., 239(1), 70-76. https:// www.doi.org/10.1006/abio.1996.0292

5. Bhat, M.M., Thakur, N.S. \& Jindal, N. (2014). Studies on the effect of drying methods and packaging on quality and shelf life of dried wild pomegranate arils. Asian Journal of Dairy and Food Research, 33(1), 18-24. https:// www.doi.org/10.5958/j.0976-0563.33.1.005

6. Brand-Williams, W., Cuvelier, M.E. \& Berset, C. (1995) Use of free radical method to evaluate antioxidant activity. Lebensmittel-Wissenschaft and Technologie, 28, 25-30.

7. Cecere, J.G., Caprioli, M., Carnevali, C., Colombo, G., Dalle-Donne, I. et al. (2016). Dietary flavonoids advance timing of moult but do not affect redox status of juvenile blackbirds (Turdus merula). Journal of Experimental Biology, 219(19), 3155-3162. https://www.doi.org/10.1242/ jeb.141424

8. Dhumal, S.S., Karale, A.R., Jadhav, S.B. \& Kad, V.P. (2014). Recent advances and the developments in the pomegranate processing and utilization: a review. Journal of Agriculture and Crop Science, 1(1), 1-17.

9. Dinis, T.C., Madeira, V.M. \& Almeida, L.M. (1994). Action of phenolic derivatives (acetaminophen, salicylate, and 5aminosalicylate) as inhibitors of membrane lipid peroxidation and as peroxyl radical scavengers. Arch Biochem Biophys., 315, 161-169. https://www.doi.org/10.1006/ abbi.1994.1485

10. Ergun, R., Lietha, R. \& Hartel, R.W. (2010). Moisture and shelf life in sugar confections. Critical Reviews in Food Science and Nutrition, 50(2), 162-192. https:// www.doi.org/10.1080/10408390802248833

11. Gill, M.I., Francisco, A., Tomas, B., Hess-Pierce, B., Holcroft, D.M. et al. (2000). Antioxidant activity of pomegranate juice and its relationship with phenolic composition and processing. Journal of Agricultural and Food Chemistry, 48(10), 4581-4589.

12. Hamid, Thakur, N.S., Thakur, A., Sharma, C., Bhatt, K. et al. (2020a). Pomegranate and its wild genotypes: nutraceutical opportunities and challenges. Annals of Phytomedicine, 9(1), 32-43. https://www.doi.org/10.21276/ ap.2020.9.1.5

13. Hamid, Thakur, N.S. \& Thakur, A. (2020b). Microencapsulation of wild pomegranate flavedo phenolics by lyophilization: Effect of maltodextrin concentration, structural morphology, functional properties, elemental composition and ingredient for development of functional beverage. LWTFood Science and Technology, 133, 110077 https:// doi.org/10.1016/j.Iwt.2020.110077

14. Hamid, Thakur, N.S., Thakur, A. \& Kumar P. (2020c). Effect of different drying modes on phenolics and antioxidant potential of different parts of wild pomegranate fruits. Scientia Horticulturae, 274, 109656 https://doi.org/10.10 16/j.scienta.2020.109656

15. Holland, D., Hatip, K. \& Bar-Yaakov, I. (2009). Pomegranate: botany, horticulture and breeding. In: Janik $\mathrm{J}$ (editor). Horticultural Reviews. NJ, USA: John Wiley \& Sons Inc., pp. 127-191. https://www.doi.org/10.1002/978047059 3776.ch2

16. Hota, M., Dahiya, D.S. \& Sharma, D.K. (2017). Effect of various drying methods on quality of pomegranate (Punica granatum L.) arils. The Bioscan, 12(2), 851-854.

17. Ilahy, R., Hdider, C., Lenucci, M.S., Tlili, I. \& Dalessandro, G. (2011). Antioxidant activity and bioactive compound changes during fruit ripening of high-lycopene tomato cultivars. Journal of Food Composition and Analysis, 24(45), 588-595.

18. Jaiswal, V., Der-Marderosian, A. \& Porter, J.R. (2010). Anthocyanins and polyphenoloxidase from dried arils of pomegranate (Punica granatum L.). Food Chemistry, 118, 11-16. https://www.doi.org/10.1016/j.foodchem.2009.01.0 95

19. Kotsiou, K. \& Tasioula-Margari, M. (2016). Monitoring the phenolic compounds of Greek extra-virgin olive oils during storage. Food Chemistry, 200, 255-262. https:// www.doi.org/10.1016/j.foodchem.2015.12.090

20. Kumar, P., Thakur, N.S., Sharma, K.D., Hamid \& Thakur, A. (2020). Effect of type and permeability behaviour of packaging material on the quality characteristics of dried carrot roundels during storage. Current Journal of Applied Science and Technology, 39(7), 83-92. https:// www.doi.org/10.9734/CJAST/2020/v39i730579

21. Mir, S.A., Wani, S.M., Ahmad, M., Wani, T.A., Gani, A. et al. (2015). Effect of packaging and storage on the physico -chemical and antioxidant properties of quince candy. Journal of Food Science and Technology, 52(11), 73137320. https://www.doi.org/10.1007/s13197-015-1819-y

22. Muzzaffar, S., Baba, W.N., Nazir, N., Masoodi, F.A., Bhat, M.M. et al. (2016). Effect of storage on physico-chemical, microbial and antioxidant properties of pumpkin (Cucurbita moschata) candy. Cogent Food and Agriculture, 2, 1163650. https://www.doi.org/10.1080/23311932.2016.1 163650

23. Nakamura, Y., Watanabe, S., Miyake, N., Kohno, H. \& Osawa, T. (2003). Dihydrochalcones: evaluation as novel radical scavenging antioxidants. Journal of Agricultural and Food Chemistry, 51(11), 3309-3312. https:// www.doi.org/doi:10.1021/jf0341060

24. Oktay, M., Gulein, I. \& Kufrevioglu, O.I. (2003). Determination of in vitro antioxidant activity of fennel (Foeniculum vulgare) seed extracts. LWT-Food Science and Technology, 36, 263-271. https://www.doi.org/10.1016/S0023-6438 (02)00226-8

25. Rawat, J.M.S., Tomar, Y.K. \& Rawat, S.S. (2012). Characterization of wild pomegranate (Punica protopunica L.) of Garhwal Himalaya. Progressive Horticulture, 44, 52-54.

26. Sakar, E. (2016). Some fruit characteristics of wild pomegranate (Punica granatum L.) genotypes from southern Anatolia region in Turkey. International Journal of Advances in Science Engineering and Technology, 4(3), 146-149.

27. Sharma, A. \& Thakur, N.S. (2016). Influence of active packaging on quality attributes of dried wild pomegranate (Punica granatum L.) arils during storage. Journal of Applied and Natural Science, 8(1), 398-404. https:// www.doi.org/doi:10.31018/jans.v8i1.806

28. Sharma, R. \& Thakur, A. (2019). Innovations in packaging for enhancing shelf life of horticultural produce. In: National Seminar on Doubling Income Through Sustainable and Holistic Agriculture; Himachal Pradesh, India. pp. 35-43.

29. Singelton, V.L. \& Rossi, J.A. (1965). Colorimetry of total phenolics with phosphomolybedic phosphotungstic acid reagent. Am J Enol Viticult., 16, 144-158.

30. Singh, R.P., Murthy, K.N.C. \& Jayaprakasha, G.K. (2002). 
Studies on the antioxidant activity of pomegranate (Punica granatum) peel and seed extract using in vitro models. Journal of Agricultural Food Chemistry, 50(1), 81-86. https://www.doi.org/10.1021/jf010865b

31. Sonawane, S. \& Arya, S.S. (2015). Effect of drying and storage on bioactive components of jambhul and wood apple. Journal of Food Science and Technology, 52(5), 2833-2841. https://www.doi.org/10.1007/s13197-014-1321-y

32. Thakur, A., Joshi, V.K. \& Thakur, N.S. (2019). Immunology and its relation with food components: an overview. International Journal of Food and Fermentation Technology, 9(1), 1-16. https://www.doi.org/10.30954/2277-9396.0 1.2019 .3

33. Thakur, A., Thakur, N.S., Hamid \& Gautam, S. (2020a) Effect of packaging on phenols, flavonoids and antioxidant activity of dried wild pomegranate (Punica granatum L.) arils prepared in solar tunnel drier. Annals of Phytomedicine, 9(2), 197-205. http://dx.doi.org/10.21276/ap.2020.9. 2.17

34. Thakur, A., Thakur, N.S., Hamid, Chauhan, M. \& Sharma, C. (2020b). Comparison of quality of anardana (dried arils) prepared in mechanical cabinet and solar tunnel drier from wild pomegranate (Punica granatum L.) fruits procured from different locations of Himachal Pradesh, India. Journal of Applied and Natural Science, 12(2), 71-78. https:// www.doi.org/10.31018/jans.vi.2247

35. Thakur, A., Thakur, N.S., Hamid \& Kumar, P. (2018). Studies on physico-chemical and antioxidant properties of wild pomegranate fruits in different locations of Himachal Pradesh, India. International Journal of Current Microbiology and Applied Sciences, 7(8), 2842-2850. https:// www.doi.org/10.20546/ijcmas.2018.708.299

36. Thakur, N.S., Bhat, M.M., Rana, N. \& Joshi, V.K. (2010). Standardization of pre-treatments for the preparation of dried arils from wild pomegranate. Journal of Food Science and Technology, 47(6), 620-625. https:// www.doi.org/10.1007/s13197-010-0091-4

37. Thakur, N.S., Kumar, D., Thakur, A., Chauhan, M. \& Kumar, P. (2017). Studies on development and storage quality of seedling mango (Mangifera indica L.) pickle of Himachal Pradesh. Indian Journal of Ecology, 44(6), 690-696.

38. Wang, Y. \& Ho, C.T. (2009). Metabolism of flavonoids. Forum of Nutrition, 61, 64-74. doi:10.1159/000212739 